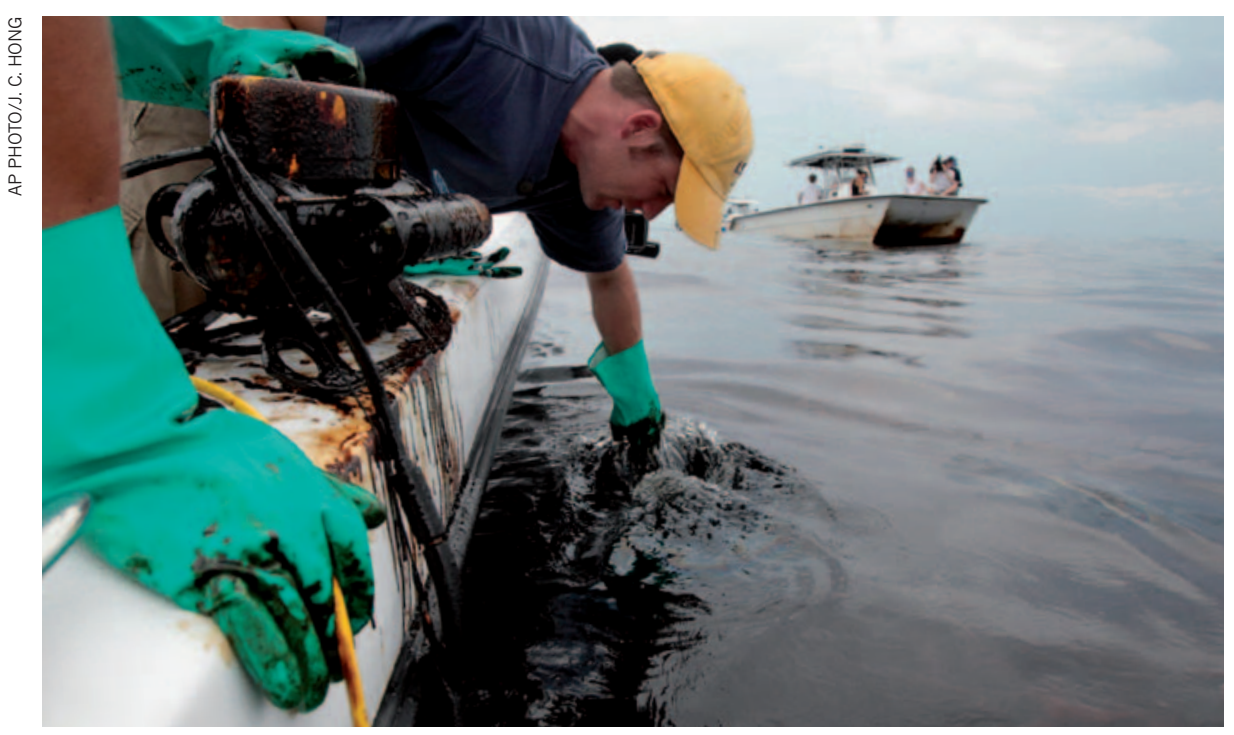

Efforts to understand the impacts of oil in the Gulf of Mexico are being delayed by funding uncertainties.

RESEARCH FUNDING

\title{
Gulf research cash still in limbo
}

\section{Scientists are frustrated by slow progress in the roll-out of funds to investigate the aftermath of Deepwater Horizon.}

\section{BY MARK SCHROPE}

A fund of half a billion dollars for research into the effects of last year's massive oil spill in the Gulf of Mexico has spent months mired in bureaucracy and political manoeuvring, leaving scientists uncertain about how or when the money will be awarded. Organizers, however, promise that relief is on the way.

On 24 May 2010, a month after the ruptured Deepwater Horizon wellhead began gushing, oil company BP announced that it was funding the Gulf of Mexico Research Initiative (GRI). The GRI will support a decade of independent research into five research themes, ranging from the physical and ecological fates of oil and other spill contaminants to improved spill-mitigation technologies.

The prospect of US $\$ 50$ million in new annual funding had thrilled researchers and politicians in the region. With the exception of projects tied to fossil-fuel exploration and development, the federal government has provided only about $\$ 4$ million $-\$ 6$ million per year for research in the Gulf of Mexico in the past decade. By contrast, Chesapeake Bay, less than one-tenth the size of the Gulf but with some highly politicized ecological concerns, has received about $\$ 20$ million-\$50 million a year.

However, problems began soon after BP appointed an international advisory council of ten researchers to oversee the GRI grants.
Hoping to avoid conflicts of interest, BP says it did not include any scientists from the Gulf research institutions likely to be bidding for funds. But regional politicians felt that they had not been adequately consulted, and argued that without that representation, funds could largely end up going to higher-profile, nonGulf institutions.

In response, BP said on 29 September that the Gulf of Mexico Alliance (GMA), a partnership of the states around the Gulf, would administer the grants. Awards would be made by an expanded advisory council of 20 members, with $\mathrm{BP}$ and the alliance each appointing half of the members. The original chair, Rita Colwell, an environmental microbiologist at Johns Hopkins University in Baltimore, Maryland, and a former director of the National Science Foundation, would remain in place.

Larry McKinney, executive director of Texas A\&M Corpus Christi's Harte Research Institute for Gulf of Mexico Studies, who has consulted on the initiative's development, says that despite his initial scepticism, BP has worked hard to move the GRI forward. "I haven't found any indication that they were doing anything but trying to get the money out," he says.

The initiative did give out $\$ 40$ million in fasttrack funds last year, allowing some research to move forward. Most of this money was apportioned as lump sums to a few Gulf state research institutions, however, limiting the broader community's access to the funds. The bigger challenge has been to develop a request for proposals (RFP) acceptable to board members and stakeholders, a process that is now inching towards its conclusion. But many researchers are baffled and exasperated by the delay.

In November, at the GMA's request, McKinney recommended ways to shape the RFP, including mandating participation of a Gulf research institute in any consortium bidding for grants. He and others also suggested that the GRI purchase or lease a dedicated research vessel, in order to simplify logistics for offshore research and compensate for the scarcity of research vessels in the region (see M. Gaskill Nature doi:10.1038/news.2010.536; 2010).

But researchers say that it became impossible to get information from the council about when to expect the RFP and what it might require of grant applicants. "You would think they were negotiating a nuclear treaty," says McKinney, "but maybe the politics

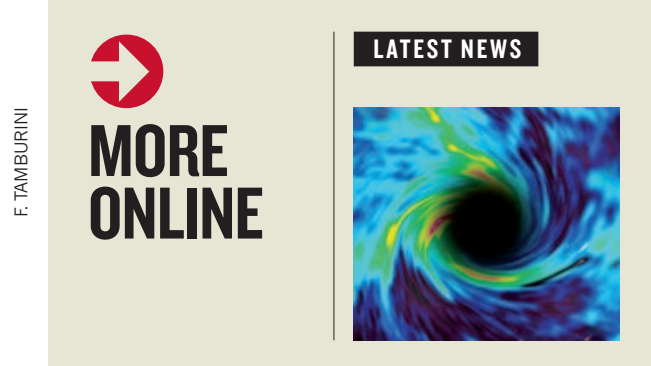

How twisted light will help spot spinning black holes go.nature.com/ dsuclu

\section{MORE NEWS}

- Sex and violence linked in the brain go.nature.com/zadiyz

- Irish science funding hangs in electoral balance go.nature.com/08samx - Lucy was a walker go.nature.com/nxlyle - Whooping cranes head back to Louisiana go.nature.com/bgzwor

\section{SPECIAL}

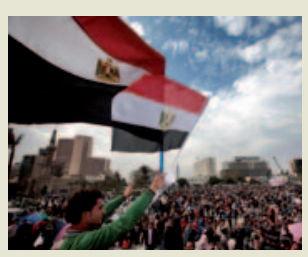

Scientists to the fore in the Arab awakening go.nature. com/ox5oag 
- around it makes that necessary."

"We are waiting patiently and doing our best to plan," adds Matthew Lee, interim associate vice-chancellor in Louisiana State University's office of research and economic development in Baton Rouge, "but in the absence of an RFP we're kind of constrained."

Other researchers have all but given up on seeing the money. "It's as far back on the stove as I can put it," says Tracy Villareal, a marine scientist at the University of Texas at Austin in Port Aransas. "We've already had most of December and all of January wasted waiting on this. I just can't afford to be sitting around and idly waiting for this thing to come out."

Ralph Portier, an environmental scientist at Louisiana State University, fears that crucial research opportunities - such as gathering some key baseline data - have already been missed. He hopes, however, that there is still time to conduct work needed to understand Deepwater Horizon's long-term legacy, and says that the delays may help to generate proposals that are informed by the latest information about the spill's effects.

Like many researchers, Nature found it difficult to get information about the GRI's progress. Council members and GMA leaders contacted by Nature said that Colwell was the only public spokesperson for the initiative; she in turn was unavailable for interview for several weeks.

Last week, however, Colwell said that an initial RFP, aimed at consortia addressing any of the five key themes, might be released as soon as next week. She expects that Gulf research institutions will be involved in these consortia, although there will be no requirement for such participation. A second RFP targeted at individual scientists and smaller groups will be released later this year. The proposal review process will be modelled on a well-established system used by the National Science Foundation.

But the council still needs to finalize protocols for data management, and how time on research vessels will be allocated, before the first RFP can be released. Colwell says that buying a dedicated ship is not an option, but that a long-term lease is possible. She declined to give specific details about the challenges of developing the RFP, but says that the delays were largely due to expanding the council's membership and gathering everyone for a first meeting, which happened in December. Despite the slow progress, "I think that the outcome will be received with satisfaction by the scientists", she says.

Others are not so sure. "Events to date raise serious questions about whether the proper structures and organizations are in place to

$\rightarrow$ NATURE.COM

For more on

Deepwater Horizon: go.nature.com/oilspill manage this process," says Villareal. "I am not optimistic about a speedy and forthright outcome."

INTELLECTUAL PROPERTY

\section{Licence rules hinder work on rare disease}

\section{Animal model off-limits to Rett-syndrome researchers.}

\section{BY ERIKA CHECK HAYDEN}

S tashed away somewhere in a freezer in Cambridge, Massachusetts, is a mouse embryo that Etienne Joly would dearly like to get his hands on.

Joly is an immunologist based in Toulouse, France, with a keen interest in Rett syndrome, an incurable and debilitating disease that almost exclusively affects young girls. The mouse, developed by a team at the Novartis Institutes for Biomedical Research in Cambridge, carries a fluorescently tagged version of the gene that is mutated in the disease. It is the perfect tool, Joly says, for testing an idea he has about Rett syndrome. But a thicket of legal restrictions puts the mouse off-limits to anyone outside Novartis, even though scientists at the company are no longer using the model in their work on Rett syndrome.

"All scientists and families are asking for is the right to look into this disease and to try to understand it better," says Joly, who has embarked on a letter-writing campaign against the restrictions. "And when you know that there is a tool, but you can't use it because some lawyer says that you can't have the materials, then you get angry." Scientists and experts in intellectual-property issues say that the case shows how science can be impeded when onerous licensing rules govern the sharing of research materials.

Girls with Rett syndrome are healthy as

\section{LIMITED ACCESS}

A 2007 survey examined what materials researchers requested from other labs.

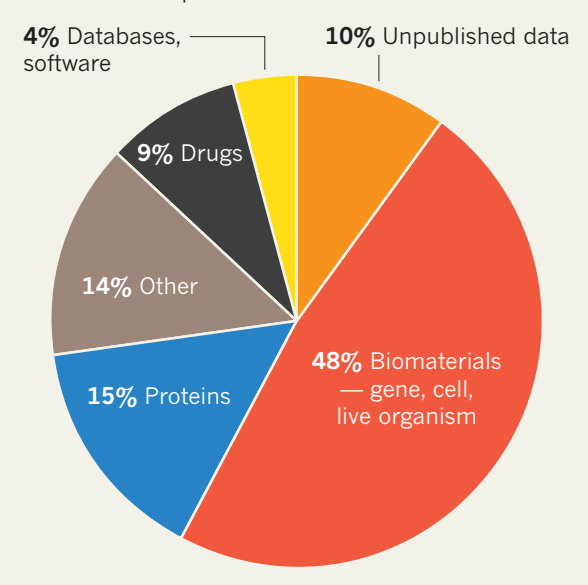

babies, then progressively lose the ability to speak, move, eat and breathe normally. Because the disease is rare, affecting just one in 10,000 to 20,000 girls, it is an unattractive target for drug companies. Academic researchers have picked up the slack, and the field has moved at breakneck speed in recent years, from the 1999 discovery that defects in the gene $M E C P 2$ cause the disease, to clinical trials of possible treatments today.

Yet no one knows how the mutation causes the disease. A few years ago, Joly, who works at the Institute of Pharmacology and Structural Biology, came up with what he calls a "slightly unconventional" idea that the Rett-syndrome gene might have a role in regulating immune responses in the central nervous system. To explore his hypothesis, Joly needed an animal model that would allow him to trace where the gene is expressed.

In 2008, Joly learned about the engineered mouse. Led by molecular biologist Cecile Blaustein, the Novartis team had joined a copy of the mouse Mecp2 gene to a copy of the gene that makes enhanced green fluorescent protein (EGFP) to produce an animal in which the gene's activity can be traced throughout the brain and body (R. S. Schmid et al. Neuroreport 19, 393-398; 2008).

But after three years of trying, neither Joly nor any other Rett-syndrome researcher has been able to gain access to the mouse. When researchers asked to share it, Blaustein and her
Were requests fulfilled?

By academics

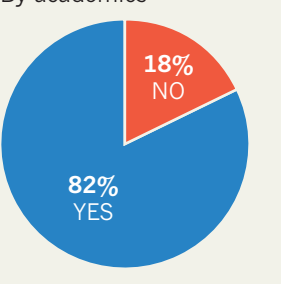

By industry
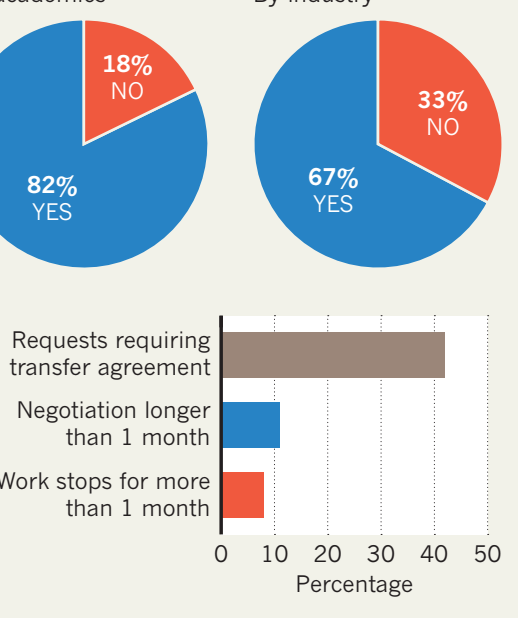